\title{
Assessing competitiveness of international contracting firms from the managerial perspective by using Analytic Network Process
}

\author{
Beliz Ozorhon (1D, Cansu Kus ${ }^{(D)}$, Semih Caglayan*iD \\ Bogazici University, Department of Civil Engineering, Istanbul, Turkey
}

\begin{abstract}
Contracting firms need to assess their competitive position in order to sustain their existence under fierce competition and an increasingly globalized business environment. Competitiveness has been investigated widely by both scholars and practitioners. However, it cannot be assessed easily and measured directly. This study aims to develop a framework to assess competitiveness of international contracting firms from the managerial perspective. In this context, competitiveness factors have been identified based on an extensive literature review. These factors are grouped under nine categories including effectiveness of strategies, managerial capabilities, organizational capabilities, efficiency of technical resources, efficiency of human resources, efficiency of financial resources, effectiveness of relationships, favorability of host country conditions, and favorability of market conditions. An Analytic Network Process (ANP) model is proposed to analyze the interrelations among the model parameters and to compute their importance weights. Analysis results suggest that "effectiveness of strategies" is the most influential cluster that contributes to the competitiveness of the contractors, followed by "organizational capabilities" and "managerial capabilities", respectively. The applicability of the proposed model is tested on ten projects, and the results are found to be satisfactory. The findings of this study are expected to guide contractors in developing appropriate strategies to pursue in international markets and selecting right projects to bid for.
\end{abstract}

\section{Keywords}

Project Management; Construction Industry; Contracting Firms; Competitiveness; Analytic Network Process Received: 21 February 2020; Accepted: 23 March 2020 ISSN: 2630-5771 (online) (C) 2020 Golden Light Publishing All rights reserved.

\section{Introduction}

The increasing number of projects in the world can be attributed to many reasons including faster product cycles, increasing currency of projects, and increasing global competitiveness [1]. No matter in what type of industry a company carries on business, achieving the competitive advantage is the common goal of the company [2]. "Competitiveness is a concept that economists, industrialists, politicians, journalists and academics frequently refer to, debate and worry about” [3].
Many definitions of competitiveness can be found in the literature. The most intuitive definition of competitiveness is "a country's share of world markets for its products” [4]. According to World Competitiveness Yearbook [5], competitiveness is "a field of economic knowledge, which analyses the facts and policies that shape the ability of a nation to create and maintain an environment that sustains more value creation for its enterprises and more prosperity for its people." 
Construction is an industry where it is necessary and beneficial to make competitive analysis and use business assessment tools [6]. There are many frameworks to analyze the competitiveness at the industry level including the Diamond Model [7], the Three Dimensions Model [8], the Double Diamond Model [9], the Nine-factor Model [10], Assets-Processes-Performance (APP) Model [11], the Competitiveness Triange [12], and Total Value Competitiveness [13]. Ofori [14] used the Diamond framework to formulate a long-term strategy for Singapore's construction industry. Momaya and Selby [15] conducted a comparison of the competitiveness of the Canadian construction industry in relation to that of the USA and Japan by adopting the APP model. Oz [16] applied the Diamond model to the Turkish construction industry. Shen et al. [13] applied Total Value Competitiveness Framework to Chinese construction industry. Mutti [17] adapted the Double Diamond for assessing the competitiveness of Brazilian contractors in the international market. Deng et al. [18] adopted Porter's Diamond Model to develop potential factors formulating the competitiveness of the construction industry, and uncovered the factors that formulate the competitiveness of the Chinese construction industry.

Contracting firms need to assess their competitive position in order to sustain their existence in an increasingly globalized and competitive environment. Besides the models developed at the industry level, many scholars tried to investigate the competitiveness factors that affect construction firms. For example, Hatush and Skitmore [19] constructed five major attributes for assessing a contractor's competitiveness during the pre-qualification and bidding process, including financial soundness, technical ability, management capability, health and safety and reputation. Drew and Skitmore [20] measured a contractor's competitiveness among bids according to the type and size of construction work and the type of client involved. Lai and Guan [21] developed a model to assess a large contractor's competitiveness by using the parameters of organizational ability, marketing ability, technical ability, financial ability, and image ability. Shen et al. [22] investigated the characteristics of construction business environment in China and identified the key parameters used in assessing contractors' competitiveness for awarding construction contracts in the market. El-Diraby et al. [23] used analytic hierarchy process (AHP) to provide an understanding of how construction companies evaluate market attractiveness and company competitiveness. Ozorhon et al. [24] used casebased reasoning to predict the level of competitiveness of a company based on a number of project, market, and host country related factors. $\mathrm{Lu}$ et al. [25] identified critical success factors (CSFs) for determining the competitiveness of a contractor in China. Sha et al. [26] developed a competitiveness index to evaluate the industrial competitiveness of ten provinces in China. Orozco et al. [27] presented a study to determine the critical variables that define the competitiveness of Chilean general contractors. Bai et al. [28] proposed an AHP model to analyze essential competitiveness factors for international contractors.

Despite the high number of studies investigating competitiveness at different levels, there is no model analyzing the competitiveness of a contractor in the international markets by considering the interrelations among the determinants of competitiveness. Given this background, the major objective of this paper is to propose an analytic network process (ANP) based competitiveness model for international contracting firms. The model explores the links among various parameters and thereby enables the computation of importance weight of each parameter.

\section{Competitiveness of contracting firms}

There are two main theories of firm competitiveness: competitive advantage and resource-based view (RBV). According to Porter [29], competitive advantage stems from the competitive strategy adopted to deal with the external forces such as opportunities and threats facing an organization [25]. Based on this view, the competitive advantage originates from external 
sources rather than internal (firm-specific) sources. Porter [30] later introduced the value chain analysis to define primary and supportive activities within a firm and proposed that the performance of those activities create competitive advantage. The second theory of firm level competitiveness that looks into the resources and capabilities/competencies of the firms is asserted by strategic management scholars. Lu et al. [25] stated that this theory suggests the determinants of competitive advantage as firmspecific resources, which are valuable, rare, nonsubstitutable, and inimitable [31-33]. Proponents shift the focus from the external to internal sources of competitive advantage, by claiming that a firm creates a competitive advantage through the accumulation, development, and use of its unique resources, capabilities, and knowledge.

\section{Research methodology}

The study was conducted in 2014 to develop a framework that can assess contracting firms' competitiveness. For this purpose, firstly, competitiveness parameters affecting construction contractors were identified through an extensive literature review. Competitiveness is defined as the ability of the firms to win contracts in international markets. The initial list of variables included 76 competitiveness factors, which were then rearranged and refined into 47 factors to prevent having several factors with similar meanings. To illustrate, "ease of entering the market" and "difficulty in exiting a segment" were merged into "enter/exit barriers". The final list was discussed with industry practitioners including a cost control and reporting director, a vice president, and two board members. Competitiveness factors for contracting firms are combined in 9 groups, namely "effectiveness of strategies", "managerial capabilities”, “organizational capabilities”, "efficiency of technical resources”, "efficiency of human resources”, "efficiency of financial resources", “effectiveness of relationships", "favorability of host country conditions", and "favorability of market conditions". Fig. 1 lists the groups and competitive factors located under them.
The proposed model takes both the external and internal factors into account. According to the model, competitiveness depends on both company related factors such as resources and capabilities, and environmental conditions along with how well these factors are exploited through strategies. In that regard, it synthesizes Porter's [29,30] work and RBV. Table 1 shows the definitions and sources of competitiveness factors.

After identifying the determinants of competitiveness, an ANP model was developed to establish and analyze the interrelations among them. The ANP is considered as the most comprehensive framework allowing one to include all the factors and criteria, tangible and intangible [47]. It is an appropriate method to use when the performance assessment model contains a number of interrelated performance criteria, most of which are qualitative rather than quantitative [36]. In this study, to analyze the competitiveness factors, ANP approach was applied. In brief, ANP model consists of the control hierarchies, clusters, elements, interrelationship between elements, and interrelationship between clusters and it is a generic form of AHP [47]. AHP is known as a powerful and flexible multicriteria decision-making method to assist decision makers when both qualitative and quantitative aspects of a decision are considered. The major principle of AHP is the comparison of elements in a decision hierarchy with respect to the controlling criterion at the next higher hierarchical level. However, AHP does not allow interdependencies between the components of a problem. The ANP, on the other hand, can accommodate interactions among the model parameters and therefore it is selected as the most appropriate tool for this research.

Many researchers in the construction industry have used ANP to analyze complicated multivariate decision making problems. Niemira and Saaty [48] made use of ANP in their study of forecasting financial crisis. Dagdeviren et al. [49] formed a model to identify total work load level of employees by ANP. 


\begin{tabular}{|c|c|c|}
\hline Effectiveness of strategies & Organizational Capabilities & Managerial Capabilities \\
\hline$\square$ & $\square$ & $\square$ \\
\hline$\square$ Diversification of strategies & $\begin{array}{l}\square \text { Knowledge and expertise in the } \\
\text { market }\end{array}$ & $\square$ Site management \\
\hline$\square$ Market selection strategies & $\square$ Experience in similar projects & $\square$ Time management \\
\hline$\square$ Project selection strategies & $\begin{array}{l}\square \text { Flexibility and adaptability to market } \\
\text { changes }\end{array}$ & $\square$ Cost management \\
\hline$\square$ Client selection strategies & $\square$ Organizational culture/structure & $\square$ Risk management $\quad \square$ Claim \\
\hline$\square$ Partner selection strategies & $\square$ Image and reputation & $\square$ Environmental management \\
\hline$\square$ Bidding strategies & & $\square$ Health and safety management \\
\hline $\begin{array}{l}\text { Efficiency of technical } \\
\text { resources }\end{array}$ & $\begin{array}{l}\text { Efficiency of human } \\
\text { resources }\end{array}$ & $\begin{array}{l}\text { Efficiency of financial } \\
\text { resources }\end{array}$ \\
\hline 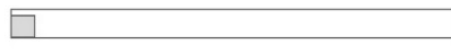 & $\square$ & $\square$ \\
\hline$\square$ Use of IT & $\square$ Current capacity of human resources & $\square$ Credibility \\
\hline$\square$ Investment in R\&D & $\square$ Development and use of human resources & $\square$ Financial status \\
\hline$\square$ Construction equipment and plant & $\begin{array}{l}\square \text { Communication and coordination } \\
\text { among departments }\end{array}$ & $\square$ Financial stability \\
\hline \multicolumn{3}{|l|}{$\square$ Innovation capability } \\
\hline Efficiency of relationships & $\begin{array}{l}\text { Favorability of host country } \\
\text { conditions }\end{array}$ & $\begin{array}{c}\text { Favorability of market } \\
\text { conditions }\end{array}$ \\
\hline$\square$ & $\square$ & $\square$ \\
\hline$\square$ Relationship with clients/owners & $\square$ Fiscal policy & $\square$ Enter/exit barriers \\
\hline $\begin{array}{l}\square \text { Relationship with suppliers / } \\
\text { subcontractors }\end{array}$ & $\square$ Socio-cultural conditions & $\square$ Project funding \\
\hline$\square$ Relationship with designers / consultants & $\square$ Economic conditions & $\square$ Quality of subcontractors / labors \\
\hline$\square$ Relationship with government entities & $\square$ Regulatory and legal restrictions & $\square$ Availability of construction materials \\
\hline$\square$ Relationship with banks and institutions & $\square$ Political conditions & $\square$ Competitive environment \\
\hline
\end{tabular}

Fig. 1. The categorized competitiveness factors

Chen and Wong [50] utilized ANP in developing a model for environmentally conscious construction planning. Ozorhon et al. [36] developed an ANP model to examine the links between the determinants of performance and observed the influences of these factors on the international construction joint venture performance. Polat and Donmez [51] proposed an ANP model to assist construction companies to select the marketing activities for which they should primarily allocate their limited resources. Dikmen et al. [52] identified the determinants of business failure in construction and used their ANP model to predict the failure likelihood of construction companies by assessing their current situation based on both companyspecific and external factors. Erdem and Ozorhon [53] developed an ANP model to examine the links between the attributes of success and compute the importance weights of these variables on the real estate project success.

A $47 \times 47$ matrix was used to determine the links between competitiveness factors. Brainstorming sessions were conducted with a team of experts to discuss the interrelations between the model parameters. Then the results were validated with previous work in the literature. 
Table 1. Definition of the competitiveness factors

\begin{tabular}{|c|c|c|}
\hline & Factor & Sources \\
\hline \multirow{6}{*}{$\begin{array}{l}\text { A. Effectiveness } \\
\text { of strategies }\end{array}$} & Diversification strategies & {$[34,35]$} \\
\hline & Market selection strategies & {$[25,35]$} \\
\hline & Project selection strategies & {$[35,45]$} \\
\hline & Client selection strategies & [35.37] \\
\hline & Partner selection strategies & {$[35,36]$} \\
\hline & Bidding strategies & {$[19,23,38,39,40]$} \\
\hline \multirow{10}{*}{$\begin{array}{l}\text { B. Managerial } \\
\text { capabilities }\end{array}$} & Quality management & {$[13,25,27,34,35,38,43]$} \\
\hline & Time management & {$[13,22,23,35,38,44,45]$} \\
\hline & Cost management & {$[13,22,23,25,35,44]$} \\
\hline & Health and safety management & {$[19,22,23,38,42,43]$} \\
\hline & Environmental management & {$[13,22,27,44]$} \\
\hline & Risk management & {$[22,25,27,34,43,44]$} \\
\hline & Site management & {$[13,25,43,44]$} \\
\hline & Claim management & {$[25,42,43]$} \\
\hline & Subcontractor management & {$[27,44,46]$} \\
\hline & Knowledge management & {$[27,35]$} \\
\hline \multirow{5}{*}{$\begin{array}{l}\text { C. Organizational } \\
\text { capabilities }\end{array}$} & Knowledge and expertise in the market & {$[22,37,40,42]$} \\
\hline & Experience in similar projects & {$[13,24,37,42,46]$} \\
\hline & Flexibility and adaptability to market changes & {$[34,35,40,43,44]$} \\
\hline & Organizational culture/structure & {$[13,23,40,42,44]$} \\
\hline & Image and reputation & {$[13,19,22,23,39,40,44]$} \\
\hline \multirow{4}{*}{$\begin{array}{l}\text { D. Efficiency of } \\
\text { technical } \\
\text { resources }\end{array}$} & Use of information technology & {$[35,39]$} \\
\hline & Innovation capability & {$[34,35]$} \\
\hline & Investment on research and development & {$[38,39]$} \\
\hline & Construction equipment and plant & {$[19,22,42,44]$} \\
\hline \multirow{3}{*}{$\begin{array}{l}\text { E. Efficiency of } \\
\text { human resources }\end{array}$} & Current capacity of human resources & {$[13,22,25,38,42,45,46]$} \\
\hline & Development and use of human resources & {$[35,46]$} \\
\hline & Communication and coordination among departments & {$[34,38,41,45,46]$} \\
\hline \multirow{3}{*}{$\begin{array}{l}\text { F. Efficiency of } \\
\text { financial } \\
\text { resources }\end{array}$} & Credibility & {$[22,42,44,46]$} \\
\hline & Financial status & {$[19,35,42,46]$} \\
\hline & Financial stability & {$[13,25,42,46]$} \\
\hline \multirow{5}{*}{$\begin{array}{l}\text { G. Effectiveness } \\
\text { of relationships }\end{array}$} & Relationship with clients/owners & {$[13,39,41,44]$} \\
\hline & Relationship with suppliers/subcontractors & {$[13,35,41]$} \\
\hline & Relationship with designers/consultants & {$[27,44]$} \\
\hline & Relationship with government entities & {$[13,24,27,41,44]$} \\
\hline & Relationship with banks and institutions & {$[41,44]$} \\
\hline \multirow{6}{*}{$\begin{array}{l}\text { H. Favorability of } \\
\text { host country } \\
\text { conditions }\end{array}$} & Regulatory and legal restrictions & {$[23,37,38]$} \\
\hline & Socio-cultural conditions & {$[23,24,38]$} \\
\hline & Economic conditions & {$[23,27,38]$} \\
\hline & Fiscal policy & {$[23,37]$} \\
\hline & Political conditions & {$[23,27]$} \\
\hline & International relations & [38] \\
\hline \multirow{5}{*}{$\begin{array}{l}\text { I. Favorability of } \\
\text { market conditions }\end{array}$} & Enter/exit barriers & [23] \\
\hline & Project funding & [24] \\
\hline & Quality of subcontractors/labors & {$[23,27]$} \\
\hline & Availability of construction materials & [23] \\
\hline & Competitive environment & {$[24,27,38]$} \\
\hline
\end{tabular}


Respondents were preferred to be experienced civil engineers, who are senior level managers. Their average experience in construction sector is 19 years. The respondents were chosen from the Turkish contracting firms that are members of the Turkish Contractors Association (TCA) and ranked among the world's Top 225 International Contractors, according to the Engineering NewsRecord (ENR). The average company age is 47.6. Ten experts participated in the data collection. Although there is no minimum number for the panel size, it is common to conduct the ANP exercise with the participation of three or more experts [52]. Table 2 provides brief information about the respondents, who attended the brainstorming sessions. It should be noted that all experts are chosen from different companies to obtain as diverse opinions as possible.

The network of interrelations was finalized based on both a synthesis of experts' opinions and literature survey. Categorization of the identified competitiveness factors leads to a two-level hierarchy, where the top level elements (clusters) are decomposed into lower level factors (node). The top level criterion, which is competitiveness, is composed of 9 clusters as mentioned above. Fig. 2 depicts the interrelations among the clusters of the model.

Table 2. Information on the respondents

\begin{tabular}{llll}
\hline No & $\begin{array}{l}\text { Company's Age } \\
\text { (Year) }\end{array}$ & $\begin{array}{l}\text { Respondent's } \\
\text { Experience } \\
\text { (Year) }\end{array}$ & Respondent's Position \\
\hline 1 & 60 & 18 & Deputy General Manager \\
2 & 50 & 15 & Tendering and Project Development Coordinator \\
3 & 65 & 20 & Business Development and Tendering Coordinator \\
4 & 21 & 12 & Business Development Manager \\
5 & 20 & 30 & Executive Committee Member \\
6 & 38 & 14 & Business Development Manager \\
7 & 76 & 10 & Business Development Manager \\
8 & 11 & 20 & Business Development and Tendering Coordinator \\
9 & 67 & 20 & Business Development Manager \\
10 & 68 & 35 & Deputy General Manager \\
\hline
\end{tabular}

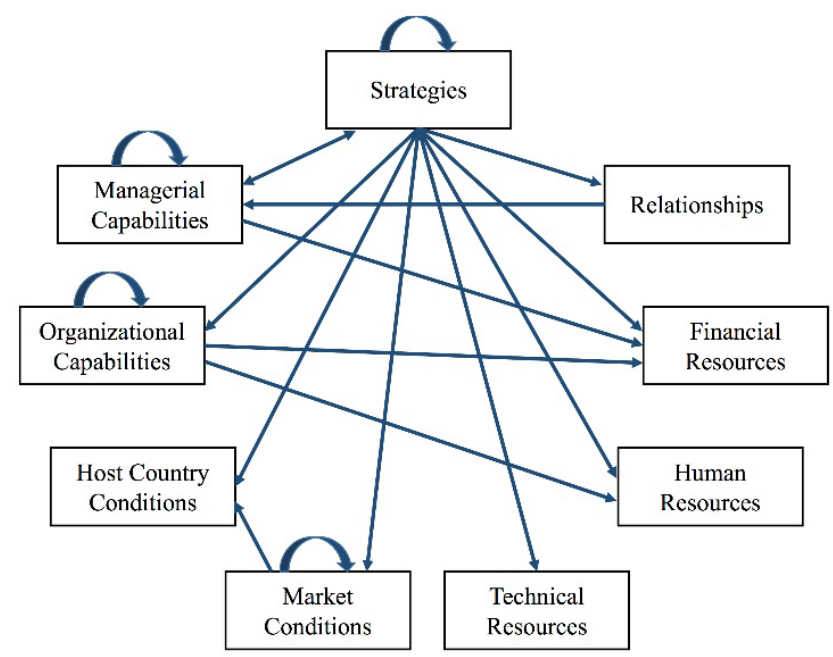

Fig. 2. Interrelations among the clusters 
Based on the model, the internal and external factors of competitiveness determine the level of "effectiveness of strategies". Strategies and financial resources affect the "managerial capabilities", whereas "organizational capabilities” depend on human resources and financial resources. "Market conditions" are affected by host country conditions. Besides the interrelations between these clusters, there are inner dependencies as well. Nodes within "strategies", "managerial capabilities”, “organizational capabilities”, and “market conditions” interact with each other.
After the model was constructed, pairwise comparison matrices were formed based on the interdependencies between the nodes. The pairwise comparisons are made using a nine-point scale. The experts were asked to evaluate these matrices, which were later used to compute the importance weights of the attributes. Tables 3-6 show some examples of the comparison matrices. These include inter-relations between and within clusters and nodes.

Table 3. Inter-dependencies between clusters with respect to "competitiveness level”

\begin{tabular}{llllllllll}
\hline Competitiveness Level (Goal) & A & B & C & D & E & F & G & H & I \\
\hline Effectiveness of strategies (A) & & 2 & 3 & 5 & 6 & 4 & 3 & 4 & 3 \\
Managerial capabilities (B) & $1 / 2$ & & $1 / 2$ & 3 & 4 & 2 & 2 & 3 & 2 \\
Organizational capabilities (C) & $1 / 3$ & 2 & & 3 & 4 & 2 & 3 & 3 & 2 \\
Efficiency of technical resources (D) & $1 / 5$ & $1 / 3$ & $1 / 3$ & & $1 / 2$ & $1 / 3$ & $1 / 2$ & $1 / 2$ & $1 / 2$ \\
Efficiency of human resources (E) & $1 / 6$ & $1 / 4$ & $1 / 4$ & 2 & & $1 / 4$ & $1 / 4$ & $1 / 3$ & $1 / 4$ \\
Efficiency of financial resources (F) & $1 / 4$ & $1 / 2$ & $1 / 2$ & 3 & 4 & & 3 & 3 & 2 \\
Effectiveness of relationships (G) & $1 / 3$ & $1 / 2$ & $1 / 3$ & 2 & 4 & $1 / 3$ & & 4 & 3 \\
Favorability of host country conditions (H) & $1 / 4$ & $1 / 3$ & $1 / 3$ & 2 & 3 & $1 / 3$ & $1 / 4$ & & 3 \\
Favorability of market conditions (I) & $1 / 3$ & $1 / 2$ & $1 / 2$ & 2 & 4 & 2 & $1 / 3$ & $1 / 3$ & \\
\hline
\end{tabular}

Table 4. Inter-dependencies between nodes with respect to "effectiveness of strategies"

\begin{tabular}{lllllll}
\hline Effectiveness of strategies (A) & A1 & A2 & A3 & A4 & A5 & A6 \\
\hline Diversification strategies (A1) & & 5 & $1 / 3$ & $1 / 4$ & $1 / 5$ & $1 / 6$ \\
Market selection strategies (A2) & $1 / 5$ & & 4 & 4 & 2 & $1 / 3$ \\
Project selection strategies (A3) & 3 & $1 / 4$ & & $1 / 2$ & $1 / 2$ & $1 / 4$ \\
Client selection strategies (A4) & 4 & $1 / 4$ & 2 & & $1 / 2$ & $1 / 4$ \\
Partner selection strategies (A5) & 5 & $1 / 2$ & 2 & 2 & & $1 / 3$ \\
Bidding strategies (A6) & 6 & 3 & 4 & 4 & 3 & \\
\hline
\end{tabular}

Table 5. Inter-dependencies between nodes with respect to "risk management"

\begin{tabular}{lllll}
\hline Risk management (B6) & B1 & B2 & B3 & B4 \\
\hline Quality management (B1) & & $1 / 4$ & $1 / 5$ & 3 \\
Time management (B2) & 4 & & 1 & 3 \\
Cost management (B3) & 5 & 1 & & 3 \\
Health and safety management (B4) & $1 / 3$ & $1 / 3$ & $1 / 3$ & \\
\hline
\end{tabular}

Table 6. Inter-dependencies between nodes with respect to "market selection strategies"

\begin{tabular}{lllll}
\hline Market selection strategies (A2) & I1 & I3 & I4 & I5 \\
\hline Enter/exit barriers (I1) & & 3 & 3 & 1 \\
Quality of subcontractors/labor (I3) & $1 / 3$ & & 1 & $1 / 2$ \\
Availability of construction materials (I4) & $1 / 3$ & 1 & & $1 / 2$ \\
Competitive environment (I5) & 1 & 2 & 2 & \\
\hline
\end{tabular}


Pairwise comparisons between parameters were performed based on brainstorming sessions of the expert team. This collaborative approach was used to achieve a more reliable model through consensus among the experts. The consistency of judgment needs to be also computed, as it can be a problem during the ANP exercise. In this step, a software package called "Super Decisions" is used to calculate the consistency ratio values (as an indicator of inconsistency of the evaluations). Saaty [54] set three acceptable levels for consistency: 0.05 for a 3 by 3 matrix, 0.08 for a 4 by 4 matrix, and 0.10 for other matrices. Consistency ratios for all matrices were found to be less than the recommended level of 0.10 as set by Saaty [54].

A synthesized matrix, called the "supermatrix", was formed by combining the pairwise comparison matrices to analyze the relationships between the nodes and clusters. A supermatrix is computed in three-step calculation; the unweighted supermatrix is formed based on scorings of pairwise comparison matrices among interacting elements as the first step, then the program calculates the weighted supermatrix by multiplying the values of the unweighted supermatrix with cluster weights on which nodes connect, and as last step a limiting supermatrix is achieved by raising the weighted supermatrix to powers until all the columns corresponding to any node concentrate on the same values. As a result, for each factor in the network, the priorities with respect to their contribution to competitiveness level were defined. The values in the limiting supermatrix are equal to the resultant priorities (importance weights) of the parameters.

\section{Results and discussion}

The importance weights of clusters and nodes are given in Table 7 and Table 8, respectively. The analysis shows that "effectiveness of strategies" is the most influential cluster that contributes to the competitiveness of the contractors. Effective strategy enables construction firms to match their activities to the changing environment and achieve superior performance in competition. Therefore, there is a need for studying contractors' competitive strategies [43]. "Effectiveness of strategies" is followed by "organizational capabilities" and “managerial capabilities”, respectively. By considering managerial capabilities such as time, cost, risk, claim, and site management, all relevant factors are rated as critical in affecting a contractor's competitiveness, except for the environment and health and safety. Managerial capabilities reflect a contractor's ability to provide clients high quality products or service. Good managerial capabilities help contractors maintain and improve their operational effectiveness and form the competitive advantages in bidding [55]. It should be noted that "efficiency of human resources" and "efficiency of technical resources" are found to be the least influencing factors affecting competitiveness. This might be because without proper strategies and skills, resources cannot be mobilized and they do not solely create competitive advantage

Table 7. Importance weights of clusters

\begin{tabular}{lll}
\hline Code & Cluster Name & Limiting \\
\hline A & Effectiveness of strategies & 0.26628 \\
B & Managerial capabilities & 0.13895 \\
C & Organizational capabilities & 0.16743 \\
D & Efficiency of technical resources & 0.03697 \\
E & Efficiency of human resources & 0.03248 \\
F & Efficiency of financial resources & 0.12334 \\
G & Effectiveness of relationships & 0.10441 \\
H & Favorability of host country conditions & 0.06689 \\
I & Favorability of market conditions & 0.06325 \\
\hline
\end{tabular}


Table 8. Importance weight nodes

\begin{tabular}{|c|c|c|c|c|c|}
\hline Code & Node & $\begin{array}{l}\text { Importance } \\
\text { Weight }\end{array}$ & Code & Node & $\begin{array}{l}\text { Importance } \\
\text { Weight }\end{array}$ \\
\hline A6 & Bidding strategies & 0.08991 & D4 & $\begin{array}{l}\text { Construction equipment } \\
\text { and plant }\end{array}$ & 0.01503 \\
\hline $\mathrm{C} 2$ & Experience in similar projects & 0.07868 & F1 & Credibility & 0.01446 \\
\hline F2 & Financial status & 0.07578 & $\mathrm{C} 4$ & $\begin{array}{l}\text { Organizational } \\
\text { culture/structure }\end{array}$ & 0.01327 \\
\hline A2 & Market selection strategies & 0.04454 & D2 & Innovation capability & 0.01249 \\
\hline C1 & $\begin{array}{l}\text { Knowledge and expertise in } \\
\text { the market }\end{array}$ & 0.04386 & H5 & Political conditions & 0.01213 \\
\hline A5 & Partner selection strategies & 0.04349 & I1 & Enter/exit barriers & 0.01194 \\
\hline G1 & $\begin{array}{l}\text { Relationship with } \\
\text { clients/owners }\end{array}$ & 0.03839 & B10 & Knowledge management & 0.01168 \\
\hline A1 & Diversification strategies & 0.03431 & B9 & $\begin{array}{l}\text { Subcontractor } \\
\text { management }\end{array}$ & 0.01123 \\
\hline F3 & Financial stability & 0.03310 & $\mathrm{H} 4$ & Fiscal policy & 0.01050 \\
\hline A4 & Client selection strategies & 0.03122 & G3 & $\begin{array}{l}\text { Relationship with } \\
\text { designers/consultants }\end{array}$ & 0.00884 \\
\hline G4 & $\begin{array}{l}\text { Relationship with } \\
\text { government entities }\end{array}$ & 0.02520 & E1 & $\begin{array}{l}\text { Current capacity of } \\
\text { human resources }\end{array}$ & 0.00810 \\
\hline B6 & Risk management & 0.02514 & G2 & $\begin{array}{l}\text { Relationship with } \\
\text { suppliers/subcontractors }\end{array}$ & 0.00768 \\
\hline G5 & $\begin{array}{l}\text { Relationship with banks and } \\
\text { institutions }\end{array}$ & 0.02430 & H6 & International relations & 0.00761 \\
\hline C3 & $\begin{array}{l}\text { Flexibility and adaptability to } \\
\text { market changes }\end{array}$ & 0.02413 & C5 & $\begin{array}{l}\text { Image and } \\
\text { reputation/public image }\end{array}$ & 0.00750 \\
\hline B3 & Cost management & 0.02402 & I3 & $\begin{array}{l}\text { Quality of } \\
\text { subcontractors/labor }\end{array}$ & 0.00659 \\
\hline A3 & Project selection strategies & 0.02279 & $\mathrm{I} 4$ & $\begin{array}{l}\text { Availability of } \\
\text { construction materials }\end{array}$ & 0.00598 \\
\hline B8 & Claim management & 0.01953 & D3 & Investment on $\mathrm{R} \& \mathrm{D}$ & 0.00593 \\
\hline $\mathrm{I} 2$ & Project funding & 0.01950 & B4 & $\begin{array}{l}\text { Health and safety } \\
\text { management }\end{array}$ & 0.00542 \\
\hline E2 & $\begin{array}{l}\text { Development and use of } \\
\text { human resources }\end{array}$ & 0.01928 & B1 & Quality management & 0.00519 \\
\hline I5 & Competitive environment & 0.01925 & E3 & $\begin{array}{l}\text { Communication and } \\
\text { coordination }\end{array}$ & 0.00510 \\
\hline H1 & $\begin{array}{l}\text { Regulatory and legal } \\
\text { restrictions }\end{array}$ & 0.01720 & B5 & $\begin{array}{l}\text { Environmental } \\
\text { management }\end{array}$ & 0.00466 \\
\hline H3 & Economic conditions & 0.01677 & D1 & Use of IT & 0.00352 \\
\hline B2 & Time management & 0.01625 & $\mathrm{H} 2$ & Socio-cultural conditions & 0.00268 \\
\hline B7 & Site management & 0.01583 & & & \\
\hline
\end{tabular}


In terms of the nodes, "bidding strategies" is found to be the most influencing competitiveness factor. Similar findings can be found in the literature as well. Good bidding technique will enable contractors to win more contracts, which in turn helps to sustain a contractor's competitiveness [25]. On the other hand, bidding is a process for a contractor to show competence through organizing its resources effectively. Contractors may not win in a bidding process if its resources are not properly organized even though they are very competent [22].

"Bidding strategies" is followed by "experience in similar projects", and "financial status". Experience in similar projects is traditionally known to be a very important source of competitive advantage, as it provides easy entrance to markets and lowers costs due to tried and proven practices/ techniques [39]. Kangari [56] stated that lack of experience in the company's line of work accounts for $18.2 \%$ of all failures. Therefore, experience is a critical issue in market entry decision and source of competitive advantage. For big-scale projects, prequalification stage is the first step of contractor selection process. It is used to investigate and assess the capabilities of the contractors to carry out a job if it is awarded to them. Financial status is one of the most important factors in the prequalification stage because financial status of a contractor indicates whether a contractor is suitable to meet obligations required by work. Hence, financial status is a very critical competitiveness factor in the construction business. Dikmen and Birgonul [39] found that experience and financial capability were the major strengths of Turkish contractors. This finding ensures the results found in this study, where experience and financial status are the most influencing competitiveness factors following bidding strategies.

According to the results, "market selection strategies" is also among the top determinants of competitiveness. A firm requires comprehensive research and analysis on macro and microenvironment of the new market before market selection and then need to build strategies to enter new regions where a firm has not been active before. This finding is similar to what has been reported previously by Lu et al. [25].

Another critical competitiveness factor is "knowledge and expertise in the market". The more knowledge and expertise the companies have in the market, the easier it becomes for the companies to get prepared for the bidding process. This factor was cited in the literature in several studies, i.e. Shen et al. [22] and Ajitabh and Momaya [40].

"Partner selection strategies" is another important factor. A key aspect of the globalization of construction activity is the increasing tendency for construction firms to co-operate strategically across national borders. Reasons for the formation of multinational consortia and joint ventures are to pool technical expertise, reduce the level of exposure to risk or to get round protectionist barriers [57]. Forming partnership combines the distinctive competencies and the complementary resources of each partner. Although it is advantageous to build a partnership, it is difficult manage because of its complexity, therefore partner selection is very critical [36].

"Relationships with clients/owners" should also be mentioned. In some markets, the clients prefer to do repeat business with the contractors, in such cases if the relationships with the clients are strong, then the companies have better chances of being awarded the contracts. Several studies mention the significance of this factor, i.e., Dikmen and Birgonul [39], Shen et al. [13], and Tan et al. [44]. "Diversification strategies" another important factor. According to Cannon and Hillebrandt [58], diversification is a major contributor to corporate growth. Firms need to adapt diversification strategies to completely utilize existing resources and capabilities. Although it is difficult and complex to coordinate different and related businesses, diversification has some advantages such as expanding product offerings or expanding into new regions. In addition, diversification creates opportunities to grow after a firm has matured and to reduce cyclical fluctuations in revenues and cash flows.

"Socio-cultural conditions of the host country", "use of IT", and "environmental management" are 
the least influencing factors affecting competitiveness of the contractors. It is interesting to note that although highly cited in the literature [59,60], the importance weight of "investment on R\&D” was found to be very low. According to Pries and Janszen [59], firms can gain competitive advantage by innovating and competing on the basis of product or process innovation. This finding may be attributed to the fact that contracting firms are reluctant to innovate, since the output of innovation is not always guaranteed [61]. Rather, contractors try to create competitive advantage by offering low cost and timely construction.

\subsection{Testing of the model}

It was required to test the suitability of the developed model with real cases. The expert team provided international project data for the research. It was requested to score their real projects for 47 competitiveness factors and for their competitiveness level. Table 9 shows information on the real projects for which the success attributes are rated. Projects are mainly big scale infrastructure projects and they are from Kazakhstan, Turkmenistan, Algeria, Libya, UAE, Morocco, Kuwait, Saudi Arabia, Qatar, and Oman.
Projects have a contract value of 50 to 780 Million USD.

Respondents evaluated their real projects through the competitiveness factors in order to test the performance of the model. Taking into account the characteristics of the projects, each respondent was required to assign a rate to the availability or success of each competitiveness factor and the level of the competitiveness of the company using the point scale from 1 to 100 . The estimated competitiveness and the actual competitiveness are compared and the results are summarized in Table 10. Table suggests that the accuracy of the model is satisfactory. The precision for prediction is found to be $\pm 5 \%$. All of the error rates are less than $10 \%$. The percentage error is calculated by Eq. 1 as follows:

Error\% $=\frac{\text { Estimated }- \text { Actual }}{\text { Actual }} \times 100 \%$

It should also be noted that the assessments are highly subjective and they reflect the experience and opinions of Turkish practitioners and the markets that the Turkish contractors operate. The projects are located in Middle East and North Africa. The data can be enriched by adding projects from all around the world and the model may be improved by incorporating the experiences of contractors from other countries.

Table 9. Information on the projects

\begin{tabular}{|c|c|c|c|c|c|}
\hline \multirow{2}{*}{ Project } & \multirow{2}{*}{ Type } & \multirow{2}{*}{$\begin{array}{l}\text { Size } \\
\text { (USD } \\
\text { Million) }\end{array}$} & \multirow{2}{*}{ Location } & \multicolumn{2}{|r|}{ Company } \\
\hline & & & & Age & Activities \\
\hline 1 & Road & 350 & Kazakhstan & 60 & General Contracting \\
\hline 2 & Bridge & 280 & Turkmenistan & 50 & General Contracting \\
\hline 3 & Road & 220 & Algeria & 65 & General Contracting \\
\hline 4 & Hospital & 50 & Libya & 21 & General Contracting and Investment \\
\hline 5 & Hotel & 100 & UAE & 20 & General Contracting and Investment \\
\hline 6 & Housing & 620 & Morocco & 38 & General Contracting \\
\hline 7 & Port & 240 & Kuwait & 76 & Infrastructure \\
\hline 8 & Airport & 625 & Saudi Arabia & 11 & General Contracting \\
\hline 9 & Metro & 780 & Qatar & 67 & Infrastructure \\
\hline 10 & Rail & 350 & Oman & 68 & General Contracting \\
\hline
\end{tabular}




\section{Conclusions}

Competitiveness is not easily understood and measured because the definition is abstract and direct assessment cannot be obtained. In this study, a framework was developed to assess the competitiveness level of construction firms. A comprehensive list of competitiveness factors was identified for this purpose. A total of 47 factors were collected in 9 interrelated groups. An ANP model was used to analyze the influence of these factors on competitiveness. Data collection was based on the expert opinions from the Turkish construction sector. The analysis shows that "effectiveness of strategies" group of factors is the most influential cluster that contributes to competitiveness, followed by "organizational capabilities" and "managerial capabilities", respectively. This implies that to succeed in the competitive business environment, contractors need to utilize appropriate strategies. Inappropriate choice of strategies may lead to lower profits, productivity, and efficiency. Besides, resources of the companies should be converted into capabilities that have the potential to increase competitiveness. Resources solely have limited capacity to create competitive advantage.

The factors presented in this study can be applied to build an orderly process to develop competitive strategy of a contracting firm. First of all, strategies employed by a firm serve as a tool to achieve firm's goals and sustain its competitive advantage. Hence, building effective strategies is the most important factor in terms of competitiveness. Secondly, firm capabilities show how successfully it converts strategies into actions and directly reflect the results of the strategies adopted. Hence, the results in this study are reasonable in terms of the importance weights of the factors. Thirdly, a firm's resources such as financial, technical, and human resources can be perceived as valuable assets that need to be mobilized to enhance competitiveness by employing appropriate strategies. Besides, relationships should be carefully managed since they affect a firm's competitive advantage. Finally, external factors such as country conditions and market conditions should be carefully monitored by contracting firms. Environmental scanning is one of the most important components of strategic analysis. Therefore, potential market search should be done to identify the opportunities and threats. A firm becomes successful to the degree to which the internal environment of the firm matches with the external environment. Therefore, a firm should analyze its capabilities and resources before entering into a new market and enhance these if necessary.

This study adopted ANP to develop and effective model to assess competitiveness. However, there are a number of limitations of the study. Firstly, the findings reflect the experiences of the Turkish contractors. A similar model may be developed to incorporate different views and experiences from other countries. Secondly, the model was validated only by 10 case studies. To have more accurate results, data should be collected from more and diverse markets.

\section{Declaration of conflicting interests}

The author(s) declared no potential conflicts of interest with respect to the research, authorship, and/or publication of this article.

\section{References}

[1] Hacker M, Doolen T (2007). Alignment at the top: a case study investigating this critical factor in project implementation. Engineering Management Journal 19(1):38-42.

[2] Ercan T, Koksal A (2016). Competitive strategic performance benchmarking (CSPB) model for international construction companies. KSCE Journal of Civil Engineering 20(5):1657-1668.

[3] Flanagan R, Jewell CA, Ericsson S, Henricsson P. Measuring construction competitiveness in selected countries. Final Report, The Research Team at the University of Reading, London, 2005.

[4] Porter ME. Building the microeconomic foundations of prosperity: findings from the microeconomic competitiveness index. Palgrave Macmillan, London, 2004.

[5] IMD. World Competitiveness Yearbook. International Institute for Management Development, Lousanne, Switzerland, 2012. 
[6] Han JG, Park HP, Ock JH, Jang HS (2015). An international competitiveness evaluation model in the global construction industry. KSCE Journal of Civil Engineering 19(3):465-477.

[7] Porter ME. Competitive advantage of nations: creating and sustaining superior performance. Simon \& Schuster, New York, 2011.

[8] Feurer R, Chaharbaghi K (1994). Defining competitiveness: a holistic approach. Management Decision, 32(2):49-58.

[9] Moon CH, Rugman AM, Verbeke A (1998). A generalized double diamond approach to the global competitiveness of Korea and Singapore. International Business Review 7(2): 135-150.

[10] Cho DS (1994). A dynamic approach to international competitiveness: the case of Korea. Asia Pacific Business Review 1(1): 17-36.

[11] Buckley PJ, Pass CL, Prescott K (1988). Measures of international competitiveness: a critical survey. Journal of Marketing Management 4(2): 175-200.

[12] Lall S. Competitiveness, Technology and Skills. Edward Elgar Publishing, Cheltenham, UK, 2001.

[13] Shen LY, Lu W, Shen Q, Li H (2003). A computeraided decision support system for assessing a contractor's competitiveness. Automation in Construction 12(5): 577-587.

[14] Ofori G (1993). Formulating a long-term strategy for developing the construction industry of Singapore. Construction Management and Economics 12(3): 219-231.

[15] Momaya K, Selby K (1998). International competitiveness of the Canadian construction industry: a comparison with Japan and the United States. Canadian Journal of Civil Engineering 25(4): 640-652.

[16] Oz O (2000) Sources of competitive advantage of Turkish construction companies in international markets. Construction Management and Economics 19(2): 135-144.

[17] Mutti CN. The drivers of Brazilian contractors' competitiveness in the international market. $\mathrm{PhD}$ Thesis, University of Reading, 2004.

[18] Deng F, Liu G, Jin Z (2012). Factors formulating the competitiveness of the Chinese construction industry: empirical investigation. Journal of Management in Engineering 29(4): 435-445.

[19] Hatush Z, Skitmore M (1997). Criteria for contractor selection. Construction Management and Economics 15(1): 19-38.

[20] Drew DS, Skitmore RM (2001). The effect of contract type and contract size on competitiveness in bidding. Construction Management and Economics 15(5): 469-489.

[21] Lai X, Guan K (2001). A study of a large-scale contractor's international competitiveness. Building Science Research of Sichuan, Sichuan Institute of Construction Science 27: 73-75.

[22] Shen LY, Li QM, Drew D, Shen QP (2004). Awarding construction contracts on multicriteria basis in China. Journal of Construction Engineering and Management 130(3): 385-393.

[23] El-Diraby TE, Costa J, Singh S (2006). How do contractors evaluate company competitiveness and market attractiveness? The case of Toronto contractors. Canadian Journal of Civil Engineering 33(5): 596-608.

[24] Ozorhon B, Dikmen I, Birgonul MT (2006). Casebased reasoning model for international market selection. Journal of Construction Engineering and Management 132(9): 940-948.

[25] Lu W, Shen L, Yam MC (2008). Critical success factors for competitiveness of contractors: China study. Journal of Construction Engineering and Management 134(12): 972-982.

[26] Sha K, Yang J, Song R (2008). Competitiveness assessment system for China's construction industry. Building Research and Information 36(1): 97-109.

[27] Orozco F, Serpell A, Molenaar K (2011). Competitiveness factors and indexes for construction companies: findings of Chile. Revista de la Construcción 10(1): 91-107.

[28] Bai S, Qi B, Liu Y, Liu G. Research on the competitiveness analysis and evaluation of international contractor based on the AHP model. Management and Service Science (MASS), International Conference IEEE, 12-14 August 2011, Wuhan, China.

[29] Porter ME. Competitive strategy: Techniques for analyzing industries and competitors. Simon \& Schuster, New York, 2008.

[30] Porter ME. Competitive advantage of nations: creating and sustaining superior performance. Simon \& Schuster, New York, 2011.

[31] Wernerfelt B (1984). A resource-based view of the firm. Strategic Management Journal 5(2): 171-180.

[32] Barney J (1991). Firm resources and sustained competitive advantage. Journal of Management 17(1): 99-120.

[33] Hamel G, Prahalad CK. Competing for the Future. Harvard Business Books, Boston, 1994. 
[34] Yates JK (1994). Construction competition and competitive strategies. Journal of Management in Engineering 10(1): 58-69.

[35] Warszawski A (1996). Strategic planning in construction companies. Journal of Construction Engineering and Management 122(2): 133-140.

[36] Ozorhon B, Dikmen I, Birgonul MT (2007). Using analytic network process to predict the performance of international construction joint ventures. Journal of Management in Engineering 23(3): 156-163.

[37] Kazaz A, Erkovan, E.Istil Adiguzel, S (2019). Tender method for technically complex construction works of public. Journal of Construction Engineering, Management \& Innovation 2(1): 1-9.

[38] Venegas CP, Alarcón CLF (1997). Selecting longterm strategies for construction firms. Journal of Construction Engineering and Management 123(4): 388-398.

[39] Dikmen I, Birgonul MT (2003). Strategic perspective of Turkish construction companies. Journal of Management in Engineering 19(1): 3340.

[40] Ajitabh A, Momaya K (2004). Competitiveness of firms: review of theory, frameworks and models. Singapore Management Review 26(1): 45-61.

[41] Keles AE, Ocal ME (2018). A study about external communication of construction firms. Journal of Construction Engineering, Management \& Innovation 1(4): 157-161.

[42] Kocak, S, Kazaz A, Ulubeyli S (2018). Subcontractor selection with additive ratio assessment method. Journal of Construction Engineering, Management \& Innovation 1(1): 1832.

[43] Tan Y, Shen L, Langston C (2012). Competition environment, strategy, and performance in the Hong Kong construction industry. Journal of Construction Engineering and Management 138(3): 352-360.

[44] Tan YT, Shen LY, Yam MCH, Lo AAC (2007). Contractor key competitiveness indicators (KCIs): a Hong Kong study. Surveying and Built Environment 18(2): 33-46.

[45] Pirotti A, Keshavarzsaleh A, Rahim FM, Zakaria N (2020). Effective factors on project success in Malaysian construction industry. Journal of Engineering, Project, and Production Management 10(1): 1-10.

[46] El-khalek HA, Aziz RF, Morgan ES (2019). Identification of construction subcontractor prequalification evaluation criteria and their impact on project success. Alexandria Engineering Journal 58(1): 217-223.

[47] Saaty TL. Decision Making with Dependence and Feedback: The Analytic Network Process. RWS Publications, Pittsburgh, 1996.

[48] Niemira MP, Saaty TL (2004). An analytical network process model for financial crisis forecasting. International Journal of Forecasting 20: 573-587.

[49] Dagdeviren M, Eraslan E, Kurt M (2005). A model to determine overall workload level of workers and its applications. Journal of Engineering and Architecture 20(4): 517-525.

[50] Chen Z, Wong CTC (2005). EnvironalPlanning: analytical network process model for environmentally conscious construction planning. Journal of Construction Engineering and Management 131(1): 92-101.

[51] Polat G, Donmez U (2009). ANP-based marketing activity selection model for construction companies. Engineering, Construction and Architectural Management 10(1): 89-111.

[52] Dikmen I, Birgonul MT, Ozorhon B, Egilmezer N (2010). Using analytic network process to assess business failure risks of construction firms. Engineering, Construction and Architectural Management 17(4): 369-386.

[53] Erdem D, Ozorhon B (2013). Assessing real estate project success using the analytic network process. Journal of Management in Engineering 31(4): 04014065.

[54] Saaty TL (1994). How to make a decision: the analytic hierarchy process. Interfaces 24(6): 19-43.

[55] Raftery J, Pasadilla B, Chiang YH, Hui ECM, Tang BS (1998) Globalization and construction industry development: implications of recent developments in the construction sector in Asia. Construction Management and Economics 16(6): 729-737.

[56] Kangari R (1988). Business failure in construction industry. Journal of Construction Engineering and Management 114(2): 172-190.

[57] Andrews J (1984). Construction project management in joint ventures in developing countries. Unibeam 15: 43-47.

[58] Cannon J, Hillebrandt PM. Diversification in the Management of Construction Firm: Aspects of Theory. Mcmillan, London, 1990.

[59] Pries F, Janszen F (1995). Innovation in the construction industry: the dominant role of the 
environment. Construction Management and Economics 13(1): 43-51.

[60] Allen RS, Helms MM (2006). Linking strategic practices and organization performance to Porter's generic strategies. Business Process Management 12(4): 433-454.

[61] Ozorhon B (2013). Analysis of construction innovation process at project level. Journal of Management in Engineering 29(4): 455-463. 